\title{
ビデオストロボスコピーの臨床応用
}

\author{
角田篤 信 $^{1)} \cdot$ 山下公 - ${ }^{21}$
}

\section{Videostroboscopy and Its Clinical Application}

\begin{abstract}
Atsunobu Tsunoda ${ }^{1)}$ and Koichi Yamashita ${ }^{21}$
The introduction of the video system is an innovative enhancement to the clinical application of stroboscopy. However, the performance of videostroboscopy is limited to some degree. The NTSC format video system can divide laryngeal movement into 30 frames or 60 fields per second and its maximum resolution is 640 by 480 pixels (picture element). Although this performance is generally sufficient for clinical applications, it has problems with finer observation of laryngeal lesions and lack of brightness occuring during observation of low tone phonation. Clinical application of videostroboscopy is useful but attention should be paid to problems caused by video format.
\end{abstract}

Key words : videostroboscopy, NTSC format, video system.

\section{はじめに}

ストロボスコピーに扔けるビデオ録画機器の導入,すな わちビデオストロボスコピーはストロボスコピーにおける 大きな技術革新であり，その有用性を著しく高めるもので ある ${ }^{1-4)}$. ビデオストロボスコピーはストロボスコピーに おける診断，記録，供覧をビデオ技術を基にして行うとい うものであり，基本的な性質は全てテレビやビデオの規格 に規定される. 本報告ではテレビ，ビデオの基本原理をふ まえ，ビデオストロボスコピーを臨床応用する上で注意す る点やその有用性について検討する。

\section{映像とその信号処理について}

映像面，画像面とは二次元空間の広がりに拉ける光の分 布であり，光そのものには明るさや色という要素がある. さらにそれらが時間的に変化するため映像情報は音響情報 に比べはるかに複雑な情報であり，これだけの情報を電気 信号, それも信号ヶーブル一本で伝達し，一つのテープで 記録するためには，何らかの工夫すなわち映像処理が必要 となる.これを可能とするのがテレビ, ビデオ技術である. テレビ, ビデオ画面は実際には細かい光のひとつひとつの 点 (画素) から構成されている. しかし, 電光揭示板のよ うにに別々に信号を送るようにすると，それこそケーブル が何万本も必要となるため,テレビにおいては細かい画素 ひとつひとつに左上から順に次々に信号を送り，その信号 を変えることで全体としてひとつの絵を形成するようにす る.これを走査といい,テレビの基本技術である（図 1 ).

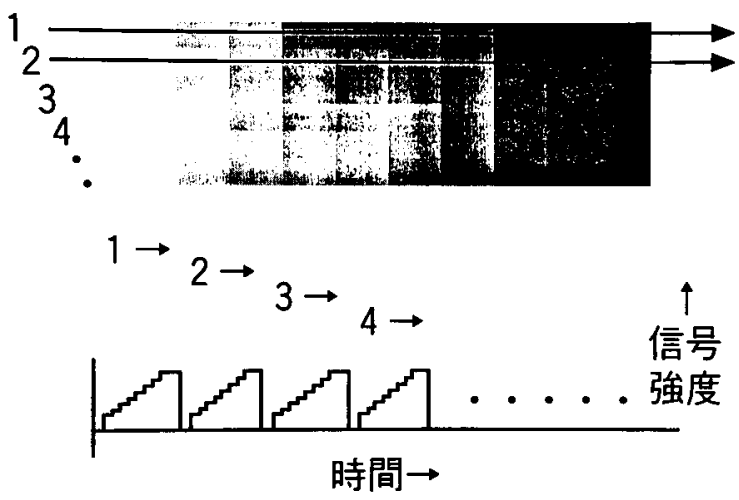

図 1 電気信号を変化させることのみで白黒のグラディ エーション画面が構成されることを示す図，信 号強度が弱いと白が, 徐々に強度を上げると色 が浱くなり，信号強度が最大となると黒が画面 上表現されるとする. 初めに図下段のように徐々 に強度を上げて信号を送る $(1 \rightarrow)$. その際， 画面上では左上から右に向かって信号の強度に 応じて画面を構成していく（走査する）。する と初めの段がグラディエーションの縞として表 現される，次いで，その下の段を走査 $(2 \rightarrow)$, さらに次々と走查することで $(3,4, \cdots \cdots \cdots)$ ひとつのグラディエーション画面が完成する. その画面の走査がいったん終了した後に，左 上に戻ってもう一度その走查をやり直し，次々 に画像を作成していくことで，時間情報が加味 される。ささらに周波数変調やフィルター好理な どをすることで同時に色を出すことができる.

1) 東京医科歯科大学耳鼻咽喉科学教室

2 ) 金沢医科大学耳鼻咽喉科学教室

1 ) Department of Otolaryngology, Tokyo Medical and Dental University

2 ) Department of Otolaryngology, Kanazawa Medical University 
これによってひとつの電気信号, 一本のケーブルで経時的 な映像信号を送ることが可能となり，映像の記録はもちろ ん一般家庭に放送するといったことが可能となる．従って， この画像は単位時間当たりの電気信号の回数, すなわち周 波数が高ければ高いほどより細かい画像の構築が可能であ り，かつ多くの画像が構成可能となる，例えば，1秒間に 1000回の信号, すなわち1000Hzでは10かける10の画素で 1 秒間に10枚という非常に荒い画像となり, 百万回の信号,

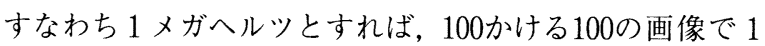
秒間に100枚というょり細かい画像となる。よって，理屈 から言えば周波数を極端に上げればきわめて細かく鮮明な 画像が出来るはずである. しかし, 周波数を上げると（周 波数帯域が広がり) 放送のチャンネル数が増やせないこと から，ある程度の妥協点で実際のビデオやテレビ放送シス テムは構築されている。これによって, テレビ, ビデオの 性能が決定し，ひいてはビデオストロボスコピーの性能が 規定される。

日本で使用されている映像のフォーマットはNTSC 規 格でその他にも PAL, SECAM という規格がある。さら にそれぞれも細分化されており，これらのフォーマットの 間には互換性はない. NTSC 規格とは1953年にアメリカ合 衆国のテレビジョンシステム委員会で白黒テレビとの両立 性を保った世界最初のテレビジョンシステムとして誕生. NTSCの名称はその, National Television System Committeeの頭文字をとったものである。その規格であ るが, 全体の画面は縦 3 横 4 の比率で構築され, 原理的に は縦に525本の縞を走査する．上から下までいったんひと つとばしで走査し次に左上に戻るまでが60分の 1 秒。いっ たんここで画面を構築し, 次の走査はそこから 1 段ずらし てまた60分の 1 秒かけて走査する，すなわち 30 分の 1 秒間 に2 回走査を行い,これでひとつの画像を完成させる。ひ とつ飛ばしで走査する方法は画面のちらつきをできるだけ 目立たなくする目的でなされるものでこれをインターレー ス方式と呼ぶ.こうして完成したひとつの画像をフレーム といい, 一回の走査でできる半分の画像をフィールドとい う. NTSC 方式では縦が525本であるから, 正方形の画素 で構成するとすれば, 横はその 3 分の 4 倍の 700 画素とな る.よって $700 \times 525$ の解像度を有する画像が得られるはず であるが, 現実には, 走査の関係上, 左から右に走査して また左に戻る際，右下まで来て左上に戻る際にそれぞれ信 号が無い時間がある。それらを差し引くと, 結果として $658 \times 493$ の画像となり, 実際ビデオの出力端子は周波数 6.2 $\mathrm{MHz}$ ，解像度 $640 \times 480$ となっている．従ってビデオから起 こした画像は通常の $35 \mathrm{~mm}$ の画像に比べると圧倒的に荒 いはずであるが, 実用上はほとんど問題ない.

また，厳密には走査の関係上，画面左上の画像と右下の 画像は厳密には微妙に時間的にずれた画像となる。理論上 1 フィールドあたり約 0.014 秒遅れとなるが, ビデオの画 像は単位時間に CCD (charge coupled device : 光を電気 信号に変換する部分）に蓄積されたデータを見ているため,
そのような微妙な時間のズレが所見に影響する事はほとん どなく, 臨床的にも問題となっていない. 以上をまとめる と, 喉頭ビデオストロボスコピーは現在のビデオ規格を元 にしている関係上, 以下のような性能ないし限界を有する 事を, 知っておく必要がある.すなわち, 時間的分解能は フィールド画面を用いることで 60 分の 1 秒まで, フレーム 画面を用いることで 30 分の 1 まで分解可能. しかし, ひと つの画像上でわずかな時間のずれが生じている．また画面 の解像度は最高でも $640 \times 480$ 画素である ${ }^{5,6)}$.

\section{ビデオストロボスコピーにおける諸問題}

次に, ストロボにビデオを使用した際に生じるいくつか の問題について検討する.

1 ) モーションスピードが変化する機種における問題点

ストロボスコピーのモーションスピードは B \& K や ATOMOS 社製の様に固定している場合（ATOMOS 社製 はさらに0.5から $2 \mathrm{~Hz}$ の間で可変) 発声周波数と無関係に 一回の声門開閉運動を決まった時間で表示する. $1.4 \mathrm{~Hz}$ 遅 延の場合, 一回の開閉運動は 1 秒間に1.4回. するとフィー ルド画面で見たときには約42から43コマ, フレーム画面で は約21コマに分解することが出来, これは常に一定である. この值は診断上特に問題となる值ではない. 一方, 現在最 も普及していると思われる永島医科器械製のように周波数 に応じてその何パーセントかの遅延周波数を生じる器機で は基本周波数によって異なってくる。この機種の場合, LMS の三つのモードがあり，それぞれ $0.25 ， 0.5 ， 1 \% た$ け周波数を遅延させて発光する. 従って, たとえば発声の 周波数が $200 \mathrm{~Hz}$ でMのポジションを選ぶと, モーションス

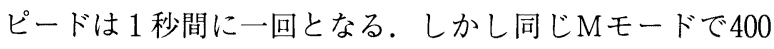
$\mathrm{Hz}$ では二秒に一回となり, さらにHのポジションでは 4 秒に一回となる。すると, ビデオ記録した際にはフレーム 画面では 1 秒間に7.5コマの分割能しか得られず, 繰り返 し再生，コマ送り観察に際して支障がでる，一方，Lのポ ジションはより細かく分割が可能であるが, 基本周波数が 一定していないときれいな画像が得られにくいため, 実際 の臨床応用においては使いにくい. 従って, この機種を用 いる際は発声周波数によってそのポジションを選ぶこと, すなわち $100 \mathrm{~Hz}$ 程度の低音発声時を観察する際はHのモー ドを, $400 \mathrm{~Hz}$ の高音発声時はLのモードで観察することが 必要となる。(なお, 永島社製は固定式にも変更可能であ $ろ^{7)}$.)

2 ) 発声周波数によるビデオストロボスコピーの問題

ストロボスコピーの発光について考えると 1 秒間の発光 時間は基本周波数一遅延周波数だけ発光し, その発光時間 は約 $0.1 \mathrm{msec}$ 以下である. すると 1 万分の 1 の画像を見て いる計算となるが, 実際にはビデオ画像上は 1 フレーム, 30 分の 1 秒の間に発光した画像を重ねてみていることとな る.よって図 2 に示したように上段の高い発声周波数では 1 フレームあたりの発光回数が多くその分データの重なり が生じ, 一方, 下段の低い発声周波数では発光回数が少な 


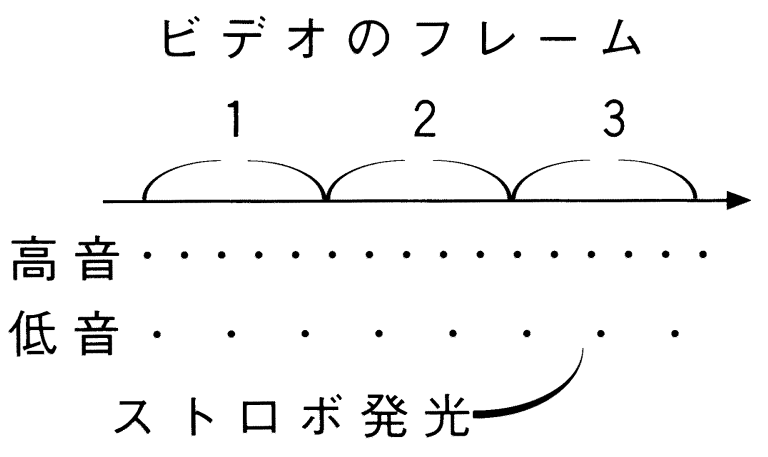

図 2 一回の発光時間 ( 1 万分の 1 秒), 並び一回の 発光強度は同一であるが, 上段の高い発声周波 数では 1 フレームあたりの発光回数は約 5 回で あり，その分データの重なりが生じる。明るさ のむらはさほど顕著にはならない。一方，下段 の低い発声周波数では発光回数が少なく，2 回 または 3 回となる.よってデータの重なりは少 ないものの，画面そのものは暗く, フレームに よる明るさのむらが生じる.

くなるため, デー夕の重なりは少ないものの, 画面そのも のは暗くなる．従って，発声周波数によって採取されるデー 夕の条件が異なることを念頭に置く必要がある。この点, 近年開発されたストロボ光源はコンピューター制御により この問題については解決されており, 今後の臨床応用が期 待される ${ }^{8)}$.

\section{ビデオストロボスコピーの有用性について}

ビデオを使用する目的はおおきくわけて 3 つあり，1） 声帯粘膜波動を静止して観察できる (ストップモーション), 2 ) 声帯粘膜波動を緩徐な速度で観察できる(スローモー ション $)^{3)}$, 声帯粘膜波動を何度も観察できる（記録再生） である。これらの点が病変の詳細な検討につながるととも に患者の負担減にも寄与する。すなわち所見がはっきり取 れるまで観察するのではなく，きれいな記録が取れた時点 で患者の所見を中止し, 先に挙げた画像の静止, スローモー ション, 繰り返し観察を通じて所見を採ることで一回の検 査時間の減少が可能である．従って，ビデオの使用並びそ の記録を前提とするビデオストロボスコピーにおいてはス トロボ光観察下における直接のストップモーションの観察 はほぼ不要であり, それも患者の負担の減少につながる。

さらに詳細な所見を採るためにストロボスコピー観察を 追加する場合, それまでの条件を変更することとなるが (発声周波数を変更したり, レンズを交換し観察部位を拡 大するなど)，その際にも初めの記録は有用な視標となる. なお，発声障害を訴える患者さんは，その他の耳鼻咽喉科 領域の患者などに比し, 自分自身の病態についてより詳し
い説明を求める傾向がある.ビデオを用いることで患者へ の病態の説明が充分なものとなり, 加療に対するインフォー ムドコンセントが容易に得られるなど様々な利点があ る ${ }^{1 \sim 4)}$. また，記録が容易であることから加療に対する病 変の経時的変化などをとらえる上でも有用である ${ }^{9)}$.

それらに加えて, 粘膜波動の存在の有無から, 病変が声 門にあるのかどうかの鑑別。さらにその粘膜波動が声門下 面から上面に上がってくるという性質から, 声門病変の上 下関係の鑑別をビデオを用い, 適宜ストップモーション, スローモーションを観察することでとらえることも可能と なっている.

$$
\text { ま と め }
$$

喉頭ストロボスコピーにビデオを導入するビデオストロ ボスコピーの有用性といくつかの問題点について検討した. なお，本論文の要旨は第10回日本喉頭科学会（金沢市）で 口演した。

\section{文献}

1) Yosida $\mathrm{T}$ et al : $\mathrm{A}$ video-tape recording system for laryngostroboscopy. 日気食会報 $30: 1 \sim 5$, 1979.

2）牟田 弘ほか：家庭用ビデオカメラを用いた喉頭ス トロボスコピー。日気食会報 $37: 19 \sim 24,1986$.

3）角田篤信ほか：喉頭ストロボスコピーの日常診療へ の利用と嗄声との関連について。日気食会報 43 ： $1 \sim 4,1992$.

4）山下公一, 角田篤信 : 喉頭のビデオストロボスコピー. 耳鼻咽喉科MOOK NO.23 11 28, 金原出版, 東京, 1992.

5）長坂新夫ほか：よくわかるテレビ・放送技術. 1 115, オーム社, 東京, 1997.

6）野々宮裕一郎ほか：新・ビデオ技術ハンドブック. 25 58, 電波新聞社, 1997.

7) 磯貝 豊ほか：私信.

8）川井田政弘ほか：喉頭ストロボスコープKAY RLS-9 100を主体としたコンピューター制御のビデオ内視鏡 画像システム。日気食会報 $49: 36 \sim 42,1998$.

9) Tsunoda $K$ et al : Stroboscopic observation of the larynx after radiation in patients with $\mathrm{T} 1$ glottic cartinoma. Acta Otolaryngol (Stockh), suppl 527: 165 166, 1997.

別冊請求先 $\bar{\top} 113-8519$ 東京都文京区湯島1-5-45 東京医科歯科大学耳鼻咽喉科学教室

角田篤信 E-mail : atsun.oto@med.tmd.ac.jp 